\author{
PATRYCJA BRÓŻEK \\ ORCID: 0000-0002-3968-6594 \\ Niezależny badacz
}

\title{
HIERARCHIA FUNKCJI I CELÓW OBOWIĄZKU NAPRAWIENIA SZKODY W POLSKIM ORAZ NIEMIECKIM PRAWIE KARNYM
}

\begin{abstract}
Abstrakt: Celem niniejszej publikacji jest ustalenie i określenie hierarchii funkcji, które spełnia na gruncie aktualnego stanu prawnego karnoprawny obowiązek naprawienia szkody, i jakie czynniki mają na to wpływ w różnych przypadkach (konfiguracjach) jego zastosowania. Zaprezentowany został również przy tym pokrótce aspekt prawnoporównawczy, to jest próba określenia, jakie jest miejsce i rola naprawienia szkody w niemieckim prawie karnym. Przeobrażenie tej instytucji w wyniku nowelizacji z 2015 roku w środek kompensacyjny spowodowało, że dyskusja na temat pełnionych przez nią funkcji oraz jej charakteru prawnego nabrała nowego wymiaru i znaczenia. Ponadto nadal może być ona orzekana jako warunek probacyjny. Ogólnie rzecz ujmując, można stwierdzić, że instytucja ta nadal realizuje przede wszystkim dwie główne funkcje, które można określić jako penalną (to jest poprzez zaspokojenie społecznego poczucia sprawiedliwości oraz oddziaływanie wychowawcze i karzące zarówno na sprawcę, jak i na społeczeństwo) oraz kompensacyjną (to jest zrekompensowanie strat i krzywd wyrządzonych przestępstwem). Pierwszoplanową rolę odgrywa obecnie jej funkcja kompensacyjna, natomiast funkcja penalna, choć doniosła, wydaje się znajdować na drugim planie. Nieco mocniej funkcja penalna jest zaakcentowana w przypadku zastosowania obowiązku naprawienia szkody w charakterze warunku probacyjnego. Instytucja ta nadal ma zatem charakter mieszany, czyli kompensacyjno-resocjalizacyjny. Nie jest instytucją „czysto” cywilistyczną, pierwiastek cywilny i karny wzajemnie się w niej przenikają i uzupełniają. Ponadto realizuje ona jeszcze inne cele. Natomiast ostateczna hierarchia realizowanych przez nią funkcji zależy tak naprawdę od okoliczności konkretnego przypadku oraz od tego, w jakiej formie zostanie zastosowana przez sąd. Z kolei niemieccy przedstawiciele doktryny prawa karnego są w zasadzie zgodni co do tego, że kompensacja nie może stanowić samodzielnego celu w prawie karnym, bowiem powinna być ona z nim odpowiednio zintegrowana.
\end{abstract}

Słowa kluczowe: szkoda, krzywda, zadośćuczynienie, funkcja kompensacyjna, funkcja penalna, prawo karne 
W wyniku nowelizacji kodeksu karnego z 2015 roku$^{1}$ obowiązek naprawienia szkody został przekształcony ze środka karnego w środek kompensacyjny ${ }^{2}$. W treści art. $46 \S 2$ k.k. ustawodawca wyraźnie zaakcentował, że przy jego orzekaniu należy stosować przepisy prawa cywilnego (z wyjątkiem przepisów o możliwości zasądzenia renty). Uzyskał on w ten sposób jeszcze bardziej cywilnoprawny charakter niż miał poprzednio. Na gruncie aktualnego stanu prawnego instytucja ta może być stosowana obok kary, jak również może mieć charakter samoistny w przypadku, gdy sąd odstąpi od jej wymierzenia na rzecz środka kompensacyjnego, a cele kary zostaną w ten sposób spełnione (art. 59 k.k. oraz art. 60 § 7 k.k.). Ponadto może być on nadal orzekany jako warunek probacyjny (art. $72 \S 2$ k.k.) ${ }^{3}$. Przekształcenie tej instytucji w środek kompensacyjny spowodowało, że polemika na temat realizowanych przez nią funkcji (ich hierarchii) oraz jej charakteru prawnego nabrała nowego wymiaru. Rekonstrukcja poglądów doktryny w tym przedmiocie ujawnia różnorodne stanowiska. Dyskusja nad tym zagadnieniem jest ciągle żywa i budzi różne kontrowersje. Głównym celem niniejszej publikacji jest zatem między innymi próba ustalenia i określenia hierarchii funkcji, które spełnia w obecnym stanie prawnym karnoprawny obowiązek naprawienia szkody i jakie czynniki mają na to wpływ w różnych przypadkach (konfiguracjach) jego zastosowania. Należy się przy tym zastanowić, która z nich ma tak naprawdę znaczenie priorytetowe. Warto przy tym również zwrócić uwagę na pewne aspekty prawnoporównawcze, to jest podjąć próbę określenia miejsca i roli naprawienia szkody w niemieckim prawie karnym.

Na wstępie niniejszych rozważań należy pokrótce nadmienić, że jeżeli chodzi o prawny charakter tej instytucji, to poglądy doktryny w tym względzie zmieniały się wielokrotnie. W zasadzie aż do czasu nowelizacji z 2015 roku część przedstawicieli doktryny uważała, że obowiązek naprawienia szkody jest instytucją mieszaną (choć ta kwestia nadal budzi wiele kontrowersji), związaną jednocześnie z prawem karnym i cywilnym ${ }^{4}$. Z kolei inni wyrażali bardziej kategoryczne stanowisko, wskazując jednoznacznie na jej cywilnoprawny charakter. Taki pogląd prezentował wówczas między innymi Marian Cieślak, który stwierdził, że obowiązek naprawienia szkody istnieje od samego początku i jest uwarunkowany prawem cywilnym, a sam fakt, że sąd nakłada go w orzeczeniu karnym, wiążąc go z celami

${ }^{1}$ Nowelizacja kodeksu karnego dokonana ustawą z 20 lutego 2015 roku o zmianie ustawy Kodeks karny oraz niektórych innych ustaw, która weszła w życie 1 lipca 2015 roku (Dz.U. z 2015 roku poz. 396 ze zm.).

2 Zob. R. Kubiak, Środek kompensacyjny w postaci obowiąku naprawienia szkody lub zadośćuczynienia - art. 46 k.k. po nowelizacji z 2015 r., „Prawo Asekuracyjne” 2016, nr 1, s. 55-68.

3 Zob. A. Marek, Naprawienie szkody wyrzadzonej przestępstwem (refleksje na tle projektu nowej kodyfikacji karnej), [w:] Problemy kodyfikacji prawa karnego. Ksiega ku czci Profesora Mariana Cieślaka, red. S. Waltoś, Kraków 1993, s. 213.

4 A. Murzynowski, Nałożenie obowiązku naprawienia skutków przestępstwa jako element nowej polityki karania, „Państwo i Prawo” 1970, z. 5, s. 716. 
kary, nie zmienia jego charakteru ${ }^{5}$. $Z$ kolei inni przedstawiciele doktryny uważali, że obowiązek naprawienia szkody ma przede wszystkim charakter karny. Taki punkt widzenia prezentowali między innymi Andrzej Bulsiewicz ${ }^{6}$, Aleksander Kafarski ${ }^{7}$, Wiesław Daszkiewicz ${ }^{8}$. Ogólnie można uznać, że ostatnie z powyższych stanowisk było dominujące aż do czasu wspomnianej nowelizacji. Jednakże w jej wyniku instytucja nabrała zdecydowanie bardziej cywilistycznego charakteru. Już przed nowelizacją, pomimo powszechnej aprobaty dla karnego charakteru obowiązku naprawienia szkody, analiza przepisów kodeksu karnego w zakresie jego unormowania pozwalała uznać, że de facto następowało tutaj zespolenie reakcji karnej z sankcją cywilnoprawną. Cywilistyczne powiązania wynikały chociażby z istoty szkody i roszczenia, które są definiowane normami prawa cywilnego. Jak słusznie wówczas stwierdził A. Marek, obowiązek naprawienia szkody lub zadośćuczynienia za doznaną krzywdę nie ma charakteru „czystego”, gdyż przy jego orzekaniu konieczne jest odnoszenie się do przepisów prawa cywilnego 9 . Albowiem pomimo tego, że przepisy prawa karnego materialnego stanowiły samodzielną podstawę dla zastosowania tej instytucji, to jednak istniała konieczność sięgnięcia do przepisów prawa cywilnego w wielu kwestiach nieuregulowanych w prawie karnym, choćby takich jak ustalenie sposobu oraz zakresu naprawienia szkody. Nawet ci, którzy akcentowali jej karny charakter, każdorazowo uzupełniali rozważania twierdzeniem o konieczności zastosowania jej w przypadku stosowania różnych cywilnoprawnych unormowań związanych ze szkodą lub krzywdą ${ }^{10}$.

Na tle zasygnalizowanego powyżej problemu charakteru prawnego tej instytucji wyłania się zasadnicze pytanie (na które odpowiedź stanowi centralny punkt niniejszej publikacji): jakie funkcje na gruncie prawa karnego spełnia aktualnie obowiązek naprawienia szkody i jaka jest jego pozycja w hierarchii? W doktrynie oraz w orzecznictwie panuje w zasadzie zgoda co do tego, że instytucja ta realizuje przede wszystkim dwie główne funkcje, które można ogólnie określić jako penalną (poprzez zaspokojenie społecznego poczucia sprawiedliwości oraz oddziaływanie wychowawcze i karzące zarówno na sprawcę, jak i na społeczeństwo) oraz kompensacyjną (zrekompensowanie strat i krzywd wyrządzonych przestępstwem) ${ }^{11}$. Różnica poglądów ujawnia się w określaniu ich hierarchii i wzajemnych relacji.

${ }^{5}$ M. Cieślak, Recenzja monografii W. Daszkiewicza „Zasądzenie odszkodowania z urzędu w polskim procesie karnym”, „Państwo i Prawo” 1971, z. 7, s. 162-163.

6 A. Bulsiewicz, Zabezpieczenie roszczeń odszkodowawczych i kar majątkowych w postępowaniu karnym, Warszawa 1975, s. 32.

7 A. Kafarski, Akcja cywilna w procesie karnym, Warszawa 1972, s. 31-32.

8 W. Daszkiewicz, Zasądzenie odszkodowania z urzędu, „Palestra” 1962, z. 9, s. 42-43; idem, Naprawienie szkody w prawie karnym, Warszawa 1972, s. $15 \mathrm{n}$.

9 A. Marek, Kodeks karny. Komentarz, Warszawa 2007, s. 126.

10 C. Kulesza, Glosa do postanowienia sktadu siedmiu sędziów Izby Karnej Sądu Najwyższego $z$ dnia 20 listopada 2001 r., WKN 18/01, „Wojskowy Przegląd Prawniczy” 2003, nr 2, s. 154.

11 Zob. R. Giętkowski, Hierarchia funkcji karnoprawnego obowiązku naprawienia szkody i jej znaczenie w praktyce, „Palestra” 2003, z. 11-12, s. 129 n. 
Warto wspomnieć, że w czasie obowiązywania kodeksu karnego z 1969 roku, kiedy obowiązek naprawienia szkody występował wyłącznie jako obowiązek probacyjny i nie był zaliczany do środków karnych ${ }^{12}$, to w doktrynie akcentowano przede wszystkim jego aspekty resocjalizacyjne oraz prewencyjne, co oznaczało nadanie kompensacji roli podrzędnej wśród pozostałych celów ${ }^{13}$. Marian Cieślak jako jeden z pierwszych umiejscowił ówcześnie kompensację wśród celów kary, obok zaspokajania społecznego poczucia sprawiedliwości, prewencji generalnej i specjalnej oraz wychowania sprawcy, wobec których posiadała ona charakter uzupełniający. Stwierdził on, że nadrzędne znaczenie należy nadać zaspakajaniu społecznego poczucia sprawiedliwości, natomiast wszelkie inne cele kary uwzględnia się tylko wówczas, gdy nie kolidują one z celem nadrzędnym ${ }^{14}$. Wyodrębniając jako osobne cele kary prewencję (ogólną i szczególną) oraz wychowanie sprawcy, analizował on relację, jaka zachodzi pomiędzy pojęciami "prewencja” oraz „wychowanie”. W konkluzji stwierdził, iż zakresy tych pojęć, co do zasady, nie pokrywają się, bowiem z jednej strony w zakres pojęcia „prewencja” wchodzi element odstraszania, który nie zawsze da się pogodzić z założeniami wychowawczymi, z drugiej zaś „wychowanie” może mieć sens szerszy, wykraczający poza zakres pojęcia prewencji ${ }^{15}$. Z kolei Z. Gostyński uznał, że w odniesieniu do naprawienia szkody można mówić o pewnym pokrywaniu się pojęć ,prewencji” (szczególnej) i ,wychowania” sprawcy. Uzasadniał on to tym, iż trudno jest dopatrzeć się w karnoprawnym obowiązku naprawienia szkody elementów odstraszania, które nie dałyby się pogodzić z założeniami wychowawczymi ${ }^{16}$. Wskazał również, iż kompensacyjna funkcja prawa karnego może być rozumiana w sposób szeroki lub wąski. W ujęciu szerokim oznacza naprawienie wszelkich szkód wyrządzonych przez czyny zabronione, w tym także tych poniesionych przez społeczeństwo. Natomiast $w$ rozumieniu wąskim skupia się ona na zaspokojeniu określonych potrzeb osób pokrzywdzonych przestępstwem ${ }^{17}$. Z kolei inni twierdzili, że przepisy kodeksu karnego normują instytucję obowiązku naprawienia szkody głównie po to, aby poprzez jej zastosowanie wychować sprawcę, a dodatkowo zadziałać odstraszająco na ogół społeczeństwa. Natomiast funkcja kompensacyjna w prawie karnym jest funkcją wtórną ${ }^{18}$. Postępujące zmiany polityczno-kryminalnych założeń kodyfikacji karnej ujawniły potrzebę nowego spojrzenia na zastosowanie kompensacji w prawie karnym. W uzasadnieniu rządowego projektu kodeksu kar-

12 Zob. A. Kafarski, op. cit., s. 32-33.

13 W. Daszkiewicz, Naprawienie szkody..., s. 17 n.

14 M. Cieślak, Polskie prawo karne. Zarys systemowego ujęcia, Warszawa 1994, s. 16, 426-427.

15 M. Cieślak, O węzlowych pojęciach związanych z sensem kary, „Nowe Prawo” 1969, nr 2, s. 207.

16 Zob. Z. Gostyński, Karnoprawny obowiązek naprawienia szkody, Katowice 1984, s. 77.

17 Z. Gostyński, Obowiazek naprawienia szkody w nowym ustawodawstwie karnym, Kraków 1999, s. 55.

18 W. Daszkiewicz, op. cit., s. 17-19. 
nego z 1997 roku wskazano, że reforma prawa karnego zmierza do istotnej zmiany statusu pokrzywdzonego, co wiąże się z przyjęciem filozofii karania odmiennej od dotychczasowej, zdominowanej przez interes państwa, sprowadzającej się w istocie do ukarania sprawcy i pomijającej sens kompensacji. Należy zatem dążyć do tego, aby prawo karne realizowało funkcję kompensacyjną w pełnym wymiarze ${ }^{19}$. Aktualnie kompensacja zyskuje na znaczeniu, zdecydowanie wykraczając poza przypisywaną jej do niedawna marginesową rolę. W doktrynie coraz mocniej akcentuje się, że konflikt pomiędzy sprawcą przestępstwa a ofiarą może być często w dużym stopniu złagodzony, jeśli wyrządzona pokrzywdzonemu szkoda zostanie naprawiona lub jeżeli sprawca $w$ jakiś sposób zapobiegł jej powstaniu ${ }^{20}$. Do czasu nowelizacji z 2015 roku kompensację na pierwszym miejscu w hierarchii funkcji realizowanych przez obowiązek naprawienia szkody umieszczał R. Giętkowski, wymieniając jako kolejne funkcję prewencyjno-wychowawczą oraz ogólnoprewencyjną (i to zarówno w odniesieniu do obowiązku naprawienia szkody orzekanego jako środek karny, jak i w charakterze warunku probacyjnego) ${ }^{21}$. Z kolei inni wyrażali pogląd, że kompensacja to jeden z celów kary, akcentując przy tym jej szerszy sens, obejmujący naprawienie wszelkich szkód wyrządzonych przestępstwem, w tym także tych poniesionych przez społeczeństwo. Według nich uznanie kompensacji za jeden z celów kary oznacza, że nie należy przeciwstawiać sobie penalnych oraz kompensacyjnych funkcji karnoprawnego obowiązku naprawienia szkody, gdyż z metodologicznego punktu widzenia taki zabieg jest nieuzasadniony. Natomiast nieco inaczej przedstawia się sytuacja kiedy in concreto dochodzi do kolizji pomiędzy kompensacyjnym a innym celem tego obowiązku, bowiem wówczas stosowne rozstrzygnięcie powinno uwzględniać właściwą hierarchię owych celów odpowiednią dla określonego przypadku ${ }^{22}$.

Nowelizacja z 2015 roku w pewien sposób rozstrzygnęła różnego rodzaju wątpliwości, jakie powstawały w związku z orzekaniem przez sądy obowiązku naprawienia szkody. Były one w dużej mierze związane z niemożnością ustalenia, jakie przepisy prawa cywilnego mogą być tutaj zastosowane ${ }^{23}$. Aktualnie instytucja ta nie jest już środkiem karnym, lecz kompensacyjnym. W związku z tym nie ma

19 Zob. Uzasadnienie rządowego projektu Kodeksu Karnego, [w:] Nowe kodeksy karne z 1997 r. z uzasadnieniami, Warszawa 1997, s. 146.

20 Por. K. Buchała, A. Zoll, Kodeks karny. Część ogólna. Komentarz, t. 1, Kraków 1998, s. 358.

21 R. Giętkowski, op. cit., s. 129 n.

22 Zob. Z. Gostyński, Obowiązek naprawienia szkody..., s. 45-56.

23 Należy wskazać, że SN w postanowieniu z 11 maja 2012 roku, IV KK 365/11, LEX nr 1215334, stwierdził, że „[p]odstawą orzekania środka karnego w postaci obowiązku naprawienia szkody są przepisy kodeksu karnego, a nie kodeksu cywilnego. Jednakże przepisy kodeksu cywilnego w tych kwestiach, których przepisy prawa karnego wprost nie uregulowały, należy stosować posiłkowo, co oznacza m.in., że wysokość odszkodowania nie może przekraczać wysokości szkody; nie można zasądzić odszkodowania w całości, gdy szkoda została w części już naprawiona itp. Przepisy prawa cywilnego mają zastosowanie przy orzekaniu obowiązku naprawienia szkody jako 
obaw, że stosowanie przy jego orzekaniu norm prawa cywilnego koliduje z obecnym statusem tego środka. Należy jednak zaznaczyć, że instytucja ta występuje również nadal w charakterze warunku probacyjnego. Głównym celem tej instytucji jest ułatwienie pokrzywdzonemu uzyskania w ramach procesu karnego pełnego zaspokojenia roszczeń cywilnoprawnych wynikających z popełnionego przestępstwa. Trzeba przy tym odnotować, że ustawodawca poza wyraźnym wskazaniem o zastosowaniu norm prawa cywilnego przy zasądzaniu obowiązku naprawienia szkody wykluczył tutaj stosowanie dyrektyw wymiaru kary i środków karnych. Zmiana ta odgrywa pewną szczególną rolę, bowiem powoduje ona w pewnym stopniu ograniczenie celów penalnych, które ma realizować ta instytucja. Oddziaływanie wychowawcze na sprawcę poprzez zastosowanie obowiązku naprawienia szkody nie jest już priorytetowym celem, jaki ma spełniać ta instytucja, bowiem nie ma tu już zastosowania dyrektywa zapobiegawczych i wychowawczych funkcji kary (art. 53 k.k.). Jednakże obowiązek naprawienia szkody orzekany jako warunek probacyjny spełnia nadal ważne cele prewencyjne oraz resocjalizacyjne. Niewątpliwie akcent został położony na funkcję kompensacyjną, jednakże funkcja penalna tej instytucji nie została całkowicie wyeliminowana. Zatem nadal spór w doktrynie dotyczy tego, która z nich jest dominująca, a także tego, jakie inne jeszcze funkcje spełnia obowiązek naprawienia szkody ${ }^{24}$.

Pomimo nowelizacji z 2015 roku instytucja nadal spełnia funkcje penalne, co powoduje konieczność odniesienia się do istoty kary, której sens ujawnia się poprzez wyjaśnienie, czym kara jest. Najogólniej można stwierdzić, że kara kryminalna jest to przewidziany ustawą karną ujemny typ reakcji na czyn zabroniony przez prawo karne skierowany wobec jego sprawcy. Łączy się ona $\mathrm{z}$ dezaprobatą zarówno dla czynu, jak i dla osoby sprawcy ${ }^{25}$. Dolegliwość jest treścią kary ${ }^{26}$. Trzeba jednak uznać, że charakterystyczne dla kary elementy, to jest odstraszanie czy odwet, trudno jest przyrównać w wymiarze jakościowym do instytucji obowiązku naprawienia szkody lub zadośćuczynienia za doznaną krzywdę. Dolegliwość wynikająca z kary jest jakościowa różna od dolegliwości wynikającej z obowiązku naprawienia szkody lub zadośćuczynienia za doznaną krzywdę, aczkolwiek można przyjąć, że pewne cele naprawienia szkody mogą być zbieżne z celami kary ${ }^{27}$. W związku z tym nadal celem tej instytucji jest spełnianie również funkcji represyjnej oraz prewencyjnej. Jednakże teoretyczne wykluczenie możliwości stosowania dyrektyw wymiaru kary przy orzekaniu obowiązku naprawienia szkody powoduje, że dużo trudniej niż kiedyś daje się przypisać mu cele kary.

środka karnego, i o ile przepisy prawa karnego nie zawierają odrębnego unormowania oraz gdy ich stosowanie nie pozostaje w sprzeczności z naturą karnoprawnego obowiązku naprawienia szkody".

24 A. Marek, Naprawienie szkody..., s. 212-213.

25 M. Cieślak, O węzłowych pojęciach..., s. 200-201; A. Marek, Prawo karne. Częsśc ogólna, Bydgoszcz 1992, s. 231.

26 A. Marek, Prawo karne. Zagadnienia teorii i praktyki, Warszawa 1997, s. 233.

27 A. Muszyńska, Naprawienie szkody wyrządzonej przestępstwem, Warszawa 2010, s. 51. 
Należy bowiem zauważyć, że funkcja wychowawcza jest mocno związana z celami kary, nie zaś z zaspokojeniem roszczeń majątkowych pokrzywdzonego, w związku z czym jest ona ulokowana bliżej funkcji represyjnej (a nie kompensacyjnej). Najogólniej można stwierdzić, że represja jest pewnego rodzaju „odpłatą” za wyrządzoną przestępstwem szkodę lub krzywdę ${ }^{28}$. Jednak trzeba zaakcentować, że rola kar nie wyczerpuje się tylko w represjonowaniu za czyny zabronione. Ich celem jest również oddziaływanie zapobiegawcze zarówno na sprawcę przestępstwa, jak i na ogół społeczeństwa, a więc spełnianie funkcji prewencyjnej ${ }^{29}$. Poprzez oddziaływanie wychowawcze (utożsamiane z resocjalizacją) prowadzić ma ona do takiego ukształtowania osobowości sprawcy, zmiany jego postawy, aby mógł negatywnie ocenić dotychczasowy sposób postępowania i wdrożyć się do wykonywania ciążących na nim obowiązków ${ }^{30}$. Należy stwierdzić, że instytucja obowiązku naprawienia szkody lub zadośćuczynienia za doznaną krzywdę niewątpliwie spełnia funkcję prewencyjną. W naprawieniu szkody ewidentnie dostrzega się walor wychowawczego oddziaływania na sprawcę ${ }^{31}$. Zastosowanie tej instytucji pozwala więc na uzmysłowienie sprawcy faktu naruszenia obowiązujących norm społecznych. Naprawienie szkody ma również oddziaływanie ogólnoprewencyjne, które polega na kształtowaniu wśród społeczeństwa przekonania o nieopłacalności popełniania przestępstw poprzez utrwalenie świadomości prawnej o konieczności wyrównania szkody.

Nałożenie na sprawcę obowiązku naprawienia szkody w pewien sposób zaspokaja społeczne poczucie sprawiedliwości. Trzeba jednak zaznaczyć, że pojęcie to nasuwa wiele wątpliwości odnośnie do jego znaczenia, istnieją bowiem różne „wymiary” społecznego poczucia sprawiedliwości. Jako zjawisko oznacza ono pewną przeciętną ocen indywidualnych $\mathrm{w}$ danym społeczeństwie ${ }^{32}$. Oceny te będą zależały od rodzaju naruszonego dobra prawnego, jego rangi z moralnego punktu widzenia, a także od miary społecznej aprobaty dla danej normy prawnej i wielu innych czynników ${ }^{33}$. Należy przy tym odnotować, że ustawodawca w treści art. 46 k.k. wyraźnie wskazał, iż obowiązek naprawienia szkody sąd może orzec „w całości albo w części”. Ponadto „zamiast” niego może orzec nawiązkę. Oznacza, to że nie ma tutaj zastosowania cywilnoprawna zasada pełnego odszkodowania. Wiąże się to z tym, że orzekanie o naprawieniu szkody lub krzywdy wyrządzonej przestępstwem pozostaje w pewnym sensie ubocznym nurtem procesu karnego.

28 K. Buchała, A. Zoll, Polskie prawo karne, Warszawa 1995, s. 13.

29 W. Wróbel, [w:] Kodeks karny. Część ogólna. Komentarz, t. 1, red. A. Zoll, Kraków 2004, s. 829.

30 Zob. A. Muszyńska, op. cit., s. 43.

31 Z. Gostyński, Obowiazek naprawienia szkody..., s. 53.

32 M. Cieślak, O węzłowych pojęciach..., s. 209.

33 B. Janiszewski, ,Sprawiedliwość” kary. Rozważania w świetle prawnych podstaw jej wymiaru, [w:] Rozważania o prawie karnym. Księga pamiątkowa z okazji siedemdziesięciolecia urodzin Profesora Aleksandra Ratajczaka, red. A. Szwarc, Poznań 1999, s. 161. 
Zatem w przypadku wystąpienia w toku postępowania trudności w orzekaniu o szkodzie lub krzywdzie, pokrzywdzony ma otwartą drogę do procesu cywilnego, jeśli zechce dochodzić przysługujących mu roszczeń. Wprawdzie pewne akcenty zostały przesunięte w kierunku elementów cywilnych tego środka, niemniej jednak cywilnoprawny charakter tej instytucji jest nadal podporządkowany jej funkcji penalnej. Trzeba przy tym również zauważyć, że zastosowanie przez sąd środka unormowanego $\mathrm{w}$ art. 46 k.k. jest możliwe tylko w przypadku skazania sprawcy (lub warunkowego umorzenia postępowania). Natomiast jeżeli sąd sprawcę uniewinni lub umorzy wobec niego postępowanie, to orzeczenie takiego obowiązku nie jest możliwe nawet pomimo złożenia stosownego wniosku o naprawienie szkody i stwierdzenia w toku procesu jej wystąpienia. Pokrzywdzony musi wówczas wystąpić z odrębnym powództwem na drogę postępowania cywilnego. Takie rozwiązanie można uznać za racjonalne, bowiem funkcja kompensacyjna w prawie karnym nie może mieć charakteru nieograniczonego. Natomiast niewątpliwie sąd każdorazowo powinien dążyć do tego, aby orzec (w możliwie jak najpełniejszym wymiarze) obowiązek naprawienia szkody na rzecz osób pokrzywdzonych przestępstwem, za które konkretny sprawca został skazany lub wobec którego umorzono warunkowo postępowanie. Zatem obecnie instytucja ta ma służyć przede wszystkim jak najszybszemu uzyskaniu przez pokrzywdzonego odszkodowania lub zadośćuczynienia, w związku z tym jej inne jej funkcje są istotne, ale mają drugorzędne znaczenie ${ }^{34}$. Przy czym należy zaznaczyć, że odszkodowanie pełni nie tylko funkcje kompensacyjną, ale posiada w sobie również pewien element dolegliwości (represji) ${ }^{35}$, w związku z czym pierwiastek kompensacyjny i represyjny nie przestają się w nim uzupełniać ${ }^{36}$.

Biorąc pod uwagę powyższe ustalenia, należy stwierdzić, że to, która z funkcji karnoprawnego obowiązku naprawienia szkody lub zadośćuczynienia za doznaną krzywdę wysuwa się na pierwszy plan, zależy przede wszystkim od okoliczności konkretnego przypadku, a także od tego w jakiej formie jest on orzekany. Można bowiem stwierdzić, że jeżeli sąd odstąpi od wymierzenia kary i poprzestanie na orzeczeniu obowiązku naprawienia szkody, to wówczas środek ten spełnia przede wszystkim funkcję penalną ${ }^{37}$. Natomiast w sytuacji, gdy jest on wymierzany obok kary, a więc gdy orzeczona kara jest zasadniczym przejawem karnoprawnej reakcji na popełniony czyn zabroniony, to wówczas instytucja ta wzmacnia funkcję represyjną oraz prewencyjną kary, ale dominuje w niej bardziej jej funk-

34 B. Janiszewski, Naprawienie szkody a cele wymiaru kary, „Czasopisma Prawa Karnego i Nauk Penalnych" 2002, nr 2, s. 53.

35 M. Cieślak, Nawiązka w polskim prawie karnym, Gdańsk 2006, s. 195.

${ }^{36}$ K. Maksymowicz, Kilka uwag obowiązu naprawienia szkody w prawie karnym, „Nowa Kodyfikacja Prawa Karnego" 9, 2001, nr 8, s. 112.

37 J. Lachowski, T. Oczkowski, Obowiazek naprawienia szkody jako środek karny, „Prokuratura i Prawo" 2007, nr 9, s. 43-44. 
cja kompensacyjna ${ }^{38}$. Generalną podstawą prawną odstąpienia od wymierzenia kary i poprzestania na orzeczeniu środka karnego stanowi przepis art. 59 k.k., w świetle którego ,[j]eżeli przestępstwo jest zagrożone karą pozbawienia wolności nieprzekraczającą 3 lat albo karą łagodniejszego rodzaju i stopnień społecznej szkodliwości czynu nie jest znaczny, sąd może odstąpić od wymierzenia kary, jeśli orzeka równocześnie środek karny, przepadek lub środek kompensacyjny, a cele kary zostaną w ten sposób spełnione". Należy więc zaznaczyć, że oprócz istnienia dwóch przesłanek dotyczących wagi czynu, znajdujących odzwierciedlenie w sankcji i stopniu społecznej szkodliwości, który nie jest znaczny, warunkiem podjęcia decyzji o odstąpieniu od wymierzenia kary jest równoczesne sięgnięcie po odpowiedni środek spełniający cele kary. Zatem zastosowanie tej instytucji jest dopuszczalne tylko wówczas, gdy orzeczony środek będzie spełniał funkcje kary, a więc należałoby przyjąć, że w przypadku obowiązku naprawienia szkody oznacza to realizację zarówno funkcji kompensacyjnej, jak i penalnej. Samoistne orzeczenie obowiązku naprawienia szkody lub zadośćuczynienia za doznaną krzywdę jest również możliwe w przypadku nadzwyczajnego złagodzenia kary (art. 60 $\S 7$ k.k.) oraz odstąpienia od jej wymierzenia na podstawie art. $61 \S 1$ k.k. Można uznać, że przy warunkowym zawieszeniu wykonania kary oraz warunkowym umorzeniu postępowania naprawienie szkody w dużym stopniu realizuje funkcję probacyjną. Warto tutaj wskazać na wyrok Sądu Najwyższego z dnia 10 sierpnia 2017 roku $^{39}$, w którym stwierdził on, że obowiązek naprawienia szkody orzekany przy warunkowym zawieszeniu kary jest fakultatywnym środkiem probacyjnym o charakterze kompensacyjnym, wychowawczym i prewencyjnym.

W tym miejscu należy pokrótce odnieść się do dorobku naukowego doktryny niemieckiej w zakresie problematyki funkcji obowiązku naprawienia szkody w prawie karnym. Trzeba nadmienić, że na gruncie tego prawa ustawodawca uregulował kilka środków prawnych mających na celu ułatwienie uzyskania odszkodowania przez ofiary przestępstw w toku procesu karnego. Takimi instytucjami są przede wszystkim naprawienie szkody orzekane w postaci warunku probacyjnego oraz powództwo adhezyjne. Zgodnie z § 56b ust. 1 niemieckiej ustawy karnej (Das Strafesetzbuch, StGB) sąd, zawieszając warunkowo realizację kary, może zobowiązać skazanego do wykonywania określonych czynności w celu zadośćuczynienia szkodzie wyrządzonej pokrzywdzonemu. Na tej podstawie może on zobowiązać sprawcę do: 1. naprawienia szkody, która wynikła z popełnionego czynu zabronionego; 2. wpłaty określonej sumy pieniężnej na rzecz stowarzyszenia użyteczności publicznej (o ile jest to wskazane ze względu na rodzaj popełnionego czynu oraz osobowość skazanego); 3. uiszczenia określonej sumy pieniężnej na rzecz Skarbu Państwa; 4. wykonania innego świadczenia o charakterze dobroczynnym. Pierwsza z wymienionych czynności ma szczególne znaczenie, bowiem sąd może

38 A. Marek, T. Oczkowski, op. cit., s. 694-695.

39 Wyrok SN z 10 sierpnia 2017 roku, II CSK 683/16, LEX nr 2349407. 
nałożyć na sprawcę obowiązki wymienione w punktach 2-4 tylko wówczas, gdy ich wykonanie nie koliduje z naprawieniem szkody wyrządzonej pokrzywdzonemu. Można więc uznać, że w zasadzie tylko pierwsza $\mathrm{z}$ tych czynności stanowi kompensatę sensu stricto na rzecz pokrzywdzonego. Należy przy tym wskazać, że sąd ma prawo do zmiany lub uchylenia swojej decyzji odnośnie orzeczonych obowiązków nawet już po uprawomocnieniu się wyroku. Ponadto w przypadku rażącego naruszenia przez sprawcę nałożonych na niego obowiązków lub orzeczonych środków sąd obligatoryjnie odwołuje warunkowe zawieszenie wykonanie kary. Zatem jest to regulacja o wiele bardziej surowa niż przewidziana w polskim prawie karnym, ponieważ na gruncie naszego prawa niewykonanie obowiązku naprawienia szkody stanowi tylko fakultatywną przesłankę odwołania stosowania wobec sprawcy środka probacyjnego. Warto również odnotować, że naprawienie szkody przez sprawcę jest $\mathrm{w}$ prawie niemieckim jedną z podstaw do nadzwyczajnego złagodzenia kary lub nawet odstąpienia od jej wymierzenia. Ponadto na gruncie tego prawa ustawodawca przewidział również możliwość umorzenia postępowania karnego przez sąd lub prokuratura (§ 153a niemieckiej ustawy karnej procesowej, StPO), jeżeli sprawca naprawi wyrządzoną ofierze szkodę, a stopień jego winy nie jest znaczny. Natomiast instytucja powództwa adhezyjnego dotyczy tylko roszczeń majątkowych wynikających z popełnionego przestępstwa. Przedmiotem takiego powództwa może być zarówno odszkodowanie, jak i zadośćuczynienie (§ 403 niemieckiej ustawy karnej procesowej, StPO) ${ }^{40}$. Możliwość zasądzenia powództwa istnieje tylko wówczas, gdy oskarżony został uznany winnym zarzucanego mu czynu lub zastosowano wobec niego środek zabezpieczający w związku z popełnionym przez niego przestępstwem. Orzeczenie zasądzające roszczenia pokrzywdzonego jest traktowane na równi z wyrokiem, jaki wydałby w tej kwestii sąd cywilny. Jednak trzeba zauważyć, że sąd karny posiada tutaj duże możliwości, aby pozostawić takie powództwo bez rozpoznania (może je odrzucić bez podania przyczyny) ${ }^{41}$. Egzekucja zasądzonych roszczeń przebiega w sposób zgodny z prawem cywilnym. Niestety w niemieckim prawie proces adhezyjny nie jest instytucją, po którą często sięgano by w praktyce (jak kiedyś miało to miejsce w polskim prawie karnym, co w konsekwencji doprowadziło do jej całkowitego usunięcia z kodeksu postępowania karnego) ${ }^{42}$.

Problematyka funkcji oraz umiejscowienia naprawienia szkody w niemieckim prawie karnym jest kwestią mocno sporną. Nie wnikając w szczegóły związane z tą materią, warto wskazać, że jeżeli chodzi o określenie funkcji i celów insty tucji niemieckiego prawa karnego mających zastosowanie w przypadku wyrządzenia

40 Zob. szerzej E. Kowalewska-Borys, D. Kużelewski, Postępowanie adhezyjne w polskim i niemieckim procesie karnym — zarys problematyki na tle prawnoporównawczym, [w:] Karnomaterialne i procesowe aspekty naprawienia szkody: w świetle kodyfikacji karnych z 1997 r. i propozycje ich zmian, red. Z. Ćwiąkalski, G. Artymiak, Warszawa 2010, s. 444-450.

41 J. Nowińska, Status prawny powoda cywilnego w procesie karnym, Kraków 2007, s. 53-52.

42 E. Kowalewska-Borys, D. Krużelewski, op. cit., s. 454-456. 
szkody lub krzywdy przez sprawcę przestępstwa, to szczególnego znaczenia nabiera teoria tak zwanej „trzeciej drogi” (dritte Spur), której propagatorem był Claus Roxin. Jest on uważany za jednego z najbardziej wpływowych dogmatyków niemieckiego prawa karnego. Ogólnie w doktrynie niemieckiego prawa wyróżnia się dwa modele, które określają funkcje instytucji służących naprawieniu szkody. Zgodnie z pierwszym z nich naprawienie szkody jest to sankcja karna, którą sąd może orzekać samoistnie. Natomiast w świetle drugiego modelu naprawienie szkody posiada charakter cywilnoprawny. Koncepcja Roxina określa miejsce instrumentów kompensacyjnych w systemie prawa karnego. Jej główna idea polega na uznaniu naprawienia szkody za samodzielną sankcję, to znaczy reakcję karną z elementami cywilnoprawnymi, która nie stanowi nowego celu kary, tylko służy zwykłym celom kary w ramach prewencji szczególnej oraz zintegrowanej. Zatem zgodnie $\mathrm{z}$ tą teorią naprawienie szkody powinno być wkomponowane $\mathrm{w}$ istniejące już instytucje prawa karnego jako trzeci sposób reakcji na popełniane przestępstwa, obok kar i środków zabezpieczających. Naprawienie szkody ma służyć przede wszystkim celom prewencyjnym ${ }^{43}$. Roxin krytycznie oceniał prawo karne oparte na założeniu, że zadaniem kary jest wyrównanie winy sprawcy. Uważał on, że różnica pomiędzy prewencją i odpłatą polega na tym, iż odpłata służy jedynie idei sprawiedliwości naprawczej i pomija wszelkie cele społeczne, podczas gdy teorie prewencyjne zmierzają do ich osiągnięcia ${ }^{44}$. Naprawienie szkody w niemieckim prawie karnym jest oddalone od cywilnoprawnego odszkodowania i stanowi on pełnoprawną część systemu sankcji karnych. Według Roxina naprawienie szkody powinno obejmować nie tylko odszkodowanie materialne, ale może mieć również postać pojednania, przeprosin, świadczenia użyteczności publicznej czy też wpłaty na fundusz dla ofiar przestępstw. Nieco odmienny pogląd zaprezentował Hans J. Hirsch, twierdząc, że naprawienie szkody nie jest ani samoistnym prawnokarnym następstwem czynu, ani sankcją karną, a raczej okolicznością wpływającą na wymiar kary. Uważa on, że zastąpienie kary kryminalnej obowiązkiem naprawienia szkody nie jest możliwe. Biorąc pod uwagę powyższe, można uznać, że niemieccy przedstawiciele doktryny praw karnego są w zasadzie zgodni co do tego, że kompensacja nie może stanowić samodzielnego celu w prawie karnym, powinna bowiem być z nim odpowiednio zintegrowana ${ }^{45}$.

Zachowując rozwagę w określeniu priorytetu jednej z wymienionych powyżej funkcji realizowanych przez obowiązek naprawienia szkody na gruncie polskiego prawa karnego, trzeba mieć na uwadze, że właściwie głównym celem tej instytucji jest stworzenie pokrzywdzonemu możliwości szybkiego oraz realnego uzyskania naprawienia wyrządzonej przestępstwem szkody lub krzywdy ${ }^{46}$. Zatem w istocie

43 Zob. A. Muszyńska, op. cit., s. 53-54 i cytowana tam literatura.

44 Z. Jędrzejewski, Bezprawność jako element przestępności czynu. Studium na temat struktury przestęstwa, Warszawa 2009, s. 106.

45 A. Muszyńska, op. cit., s. 56-58.

46 Zob. A. Marek, Obowiazek naprawienia..., s. 205 n. 
sprowadza się to do pewnego rodzaju postępowania cywilnego w ramach procesu karnego ${ }^{47}$. Pokrzywdzony musi mieć więc tutaj zapewnioną podobną ochronę swojego interesu, jak w przypadku procesu cywilnego. Instytucja ta realizuje aktualnie przede wszystkim dwie główne funkcje, które można ogólnie określić jako penalną (poprzez zaspokojenie społecznego poczucia sprawiedliwości oraz oddziaływanie wychowawcze i karzące zarówno na sprawcę, jak i na społeczeństwo) oraz kompensacyjną (zrekompensowanie strat i krzywd wyrządzonych przestępstwem). Można uznać, że pierwszoplanową rolę odgrywa obecnie funkcja kompensacyjna, natomiast funkcja penalna, choć doniosła, wydaje się znajdować na drugim planie. W wyniku nowelizacji z 2015 roku funkcja kompensacyjna została mocniej wyeksponowana, zwłaszcza w przypadku obowiązku naprawienia szkody orzekanego na podstawie art. 46 k.k. Natomiast w sytuacji zastosowania tej instytucji w charakterze warunku probacyjnego wciąż ważną rolę pełni jej funkcja penalna. Można zatem przyjąć, że nadal posiada ona mieszany charakter (kompensacyjno-resocjalizacyjny). Nie jest ona instytucją ,"czysto” cywilistyczną. Nie posiada ona charakteru wyłącznie kompensacyjnego. Prawo cywilne określa tutaj tylko pewne ramy, do których prawo karne wprowadza własne specyficzne modyfikacje. Wprawdzie pewne akcenty zostały tutaj przesunięte w kierunku elementów cywilnych tego środka, to jednak cywilnoprawny charakter tej instytucji jest nadal podporządkowany jej funkcji penalnej. Nieco mocniej funkcja ta jest zaakcentowana w przypadku orzekania obowiązku naprawienia szkody w charakterze warunku probacyjnego. Kompensacyjny charakter tego środka eksponuje przede wszystkim to, że możliwość jego zastosowania uzależniona jest od istnienia konkretnej ofiary przestępstwa oraz od wystąpienia szkody wynikłej z jego popełnienia. Zatem pierwiastek cywilny i karny wzajemnie się przenikają i uzupełniają. To, która z tych funkcji wysuwa się na pierwszy plan, zależy również od tego, w jakiej formie instytucja ta jest orzekana, bowiem jeżeli sąd odstąpi od wymierzenia kary i poprzestanie na orzeczeniu obowiązku naprawienia szkody, to wówczas środek ten spełnia przede wszystkim funkcję penalną ${ }^{48}$. Natomiast w sytuacji, gdy jest on zasądzany obok kary, a więc gdy zastosowana kara jest zasadniczym przejawem reakcji na popełniony czyn zabroniony, to wówczas instytucja ta wzmacnia funkcję represyjną oraz prewencyjną tej kary, ale dominuje w niej raczej funkcja kompensacyjna ${ }^{49}$.

W związku z tym, że kompensacja jest tylko jednym z celów karnoprawnego obowiązku naprawienia szkody, to in concreto może dojść do kolizji pomiędzy tą funkcją, a jakimś innym celem tej instytucji. Rozstrzygnięcie powinno uwzględniać właściwą hierarchię celów, jakie instytucja ta powinna w konkretnym przy-

47 M. Królikowski, R. Zawłocki, Prawo karne, Warszawa 2015, s. 359-360.

48 J. Lachowski, T. Oczkowski, Obowiqzek naprawienia szkody jako środek karny, „Prokuratura i Prawo" 2007, nr 9, s. 43-44.

49 A. Marek, T. Oczkowski, op. cit., s. 694-695. 
padku spełniać, biorąc przy tym pod uwagę całokształt okoliczności danej sprawy. Można więc przypuszczać, że spór dotyczący tego, jakie funkcje ta instytucja realizuje i która z nich ma priory tetowe znaczenie, będzie toczył się nadal. Ponadto wątpliwości będą dotyczyć również tego, czy obowiązek naprawienia szkody jest instytucją prawa cywilnego, z której korzysta prawa karne w celu realizacji określonych celów, czy może instytucja ta posiada penalną genezę (a więc jaki charakter ona posiada). Nieco inaczej kwestia ta wygląda w prawie niemieckim, w którym można wyróżnić dwa modele, które określają funkcje instytucji służących naprawieniu szkody. Zgodnie z pierwszym z nich naprawienie szkody to sankcja karna, którą sąd może orzekać samoistnie. Natomiast w świetle drugiego modelu naprawienie szkody posiada charakter cywilnoprawny. Jednak niemieccy przedstawiciele doktryny prawa karnego są w zasadzie zgodni co do tego, że kompensacja nie może stanowić w jego ramach samodzielnego celu, ponieważ musi być $\mathrm{z}$ nim odpowiednio zintegrowana.

\title{
HIERARCHY OF FUNCTIONS OF THE OBLIGATION TO REDRESS FOR DAMAGE IN POLISH AND GERMAN CRIMINAL LAW
}

\begin{abstract}
Summary
The purpose of this publication is to establish and define the hierarchy of functions that, in the current legal situation, are served by the criminal law obligation to redress for damage and what factors influence it in various cases (configurations) of its application. At the same time, the comparative legal aspect is also briefly presented, that is, an attempt to define the place and role of redressing for damage in German criminal law. The transformation of this institution into a compensatory measure as a result of the 2015 amendment made the discussion about its functions and its legal nature take on a new dimension and meaning. Moreover, it can still be adjudicated as a probation condition. In general, it can be stated that this institution still performs, above all, two main functions, which can be defined as penal (that is, by satisfying the social sense of justice and through its educational and punishing effects on both the perpetrator and society) and compensatory (that is, compensating for losses and harms caused by the crime). Currently, its compensatory function plays the leading role, while the penal function, although important, seems to be in the background. The penal function is emphasized slightly more when the obligation to redress for damage is adjudicated as a probation condition. However, despite this, this institution still has a mixed character, that is, compensatory and social rehabilitation. It is not a "pure" civilian institution; it is not solely compensatory. The civil and criminal elements interpenetrate and complement each other. In addition, it has other goals. However, the final hierarchy of functions performed by it depends in fact on the circumstances of a specific case, and on the form in which this institution is used by the court. On the other hand, German representatives of the criminal law doctrine generally agree that compensation cannot constitute an independent goal in criminal law, as it should be properly integrated with it.
\end{abstract}

Keywords: damage, harm, redress, compensatory function, penal function, criminal law 


\section{BIBLIOGRAFIA}

Bojarski T., Nowe środki karne i formy załatwiania spraw karnych, [w:] Nowe prawo karne procesowe. Księga ku czci Profesora Wiesława Daszkiewicza, red. T. Nowak, Poznań 1999.

Buchała K., Zoll A., Kodeks karny. Część ogólna. Komentarz, t. 1, Kraków 2000.

Buchała K., Zoll A., Polskie prawo karne, Warszawa 1995.

Bulsiewicz A., Zabezpieczenie roszczeń odszkodowawczych i kar majątkowych $w$ postępowaniu karnym, Warszawa 1975.

Cieślak M., O węzłowych pojęciach zwiąanych z sensem kary, „Nowe Prawo” 1969, nr 2, s. 195-213.

Cieślak M., Polskie prawo karne. Zarys systemowego ujęcia, Warszawa 1994.

Cieślak M., Recenzja monografii W. Daszkiewicza „Zasądzenie odszkodowania z urzędu w polskim procesie karnym”, „Państwo i Prawo” 1971, nr 7.

Cieślak W., Nawiazka w polskim prawie karnym, Gdańsk 2006.

Daniluk P., Glosa do postanowienia SN z dnia 6 marca 2008 r., III KK 345/07 — aprobujaca, „Przegląd Sądowy” 2009, nr 5.

Daszkiewicz W., Naprawienie szkody w prawie karnym, Warszawa 1972.

Daszkiewicz W., Zasądzenie odszkodowania z urzędu, „Palestra” 1962, nr 9, s. 41-52.

Falandysz L., Pokrzywdzony w prawie karnym i wiktymologii, Warszawa 1980.

Giętkowski R., Hierarchia funkcji karnoprawnego obowiązku naprawienia szkody i jej znaczenie w praktyce, „Palestra” 2003, z. 11-12, s. 128-138.

Gostyński Z., Karnoprawny obowiąek naprawienia szkody, Katowice 1984.

Gostyński Z., Obowiązek naprawienia szkody w nowym ustawodawstwie karnym, Kraków 1999.

Janiszewski B., ,Sprawiedliwość” kary. Rozważania w świetle prawnych podstaw jej wymiaru, [w:] Rozważania o prawie karnym. Księga pamiatkowa z okazji siedemdziesięciolecia urodzin Profesora Aleksandra Ratajczaka, red. A. Szwarc, Poznań 1999.

Janiszewski B., Naprawienie szkody a cele wymiaru kary, „Czasopisma Prawa Karnego i Nauk Penalnych" 2002, nr 2, s. 49-54.

Kafarski A., Akcja cywilna w procesie karnym, Warszawa 1972.

Kowalska-Borys E., Krużelewski D., Postępowanie adhezyjne w polskim i niemieckim procesie karnym - zarys problematyki na tle porównawczym, [w:] Karnomaterialne i procesowe aspekty naprawienia szkody w świetle kodyfikacji karnych z 1997 r. i propozycji ich zmian, red. Z. Ćwiąkalski i G. Artymiak, Warszawa 2010.

Królikowski M., Zawłocki R., Prawo karne, Warszawa 2015.

Kubiak R., Środek kompensacyjny w postaci obowiązu naprawienia szkody lub zadośćuczynienia art. 46 k.k. po nowelizacji z 2015 r., „Prawo Asekuracyjne” 2016, nr 1, s. 55-68.

Kulesza C., Glosa do postanowienia składu siedmiu sędziów Izby Karnej Sądu Najwyższego z dnia 20 listopada 2001 r., WKN 18/01, „Wojskowy Przegląd Prawniczy” 2003, nr 2.

Lachowski J., Oczkowski T., Obowiazek naprawienia szkody jako środek karny, „Prokuratura i Prawo" 2007, nr 9.

Maksymowicz K., Kilka uwag obowiazku naprawienia szkody w prawie karnym, „Nowa Kodyfikacja Prawa Karnego" 9, 2001, nr 8, s. 112.

Marek A., Kodeks karny. Komentarz, Warszawa 2010.

Marek A., Naprawienie szkody wyrzadzonej przestępstwem (refleksje na tle projektu nowej kodyfikacji karnej), [w:] Problemy kodyfikacji prawa karnego. Księga ku czci Profesora Mariana Cieślaka, red. S. Waltoś, Kraków 1993.

Marek A., Prawo karne. Część ogólna, Bydgoszcz 1992.

Marek A., Prawo karne. Zagadnienia teorii i praktyki, Warszawa 1997.

Murzynowski A., Nałożenie obowiązu naprawienia skutków przestęstwa jako element nowej polityki karania, „Państwo i Prawo” 1970, z. 5.

Muszyńska A., Naprawienie szkody wyrządzonej przestępstwem, Warszawa 2010. 
Muszyńska A., Zmiany w zakresie środków karnych o charakterze majątkowym; uwagi na tle nowelizacji z 2015 roku, „Przegląd Prawa i Administracji” 100, 2015, cz. 2.

Nowińska J., Status prawny powoda cywilnego w procesie karnym, Kraków 2007.

Stefański R.A., Kompensacyjna rola środka karnego obowiazku naprawienia szkody, „Czasopismo Prawa Karnego i Nauk Penalnych" 2002, nr 2.

Szczucki K., [w:] Kodeks karny. Część ogólna, t. 2. Komentarz do art. 32-116, red. M. Królikowski, R. Zawłocki, Warszawa 2017.

Wróbel W., [w:] Kodeks karny. Część ogólna. Komentarz, t. 1, red. A. Zoll, Kraków 2004.

Zoll A., Materialnoprawna problematyka warunkowego umorzenia postępowania karnego, Warszawa-Kraków 1973. 